\title{
THE EVALUATION OF RIVER BASIN DEVELOPMENT
}

\author{
Hubert Marshali*
}

I

\section{INTRODUCTION}

Governments, like private citizens, are faced with the problem of apportioning scarce resources among almost insatiable and competing demands. This fact has led students of government finance to advance the principle of "maximum social advantage," which holds that since resources are limited, they must be allocated among alternative ends in such a way as to yield maximum satisfaction to the members of society. Actually, the principle requires that decision-makers seek answers to two questions in connection with each expenditure proposal. First, it must be asked whether the social benefit derived from a governmental expenditure is greater or less than the aggregate personal benefit which the taxpayers would have derived from the private use of these funds. If greater, according to the principle, the government expenditure is justified; if less, it is not warranted. And second, assuming an expenditure is to be made, it must be asked whether the social advantage is greater if the money is spent on activity $A$ or on activity $B$. Thus, the principle requires not only the comparison of alternative expenditures, but a decision as to whether any public expenditure is warranted in light of the sacrifices that taxpayers will be asked to make.

This consideration of alternative uses of limited resources constitutes the heart of the budget process. No doubt, budget-makers at lower echelons of the bureaucracy are not particularly aware of the weighing and evaluating which form a part of their jobs; these processes are done almost subconsciously where policies are well established and the sums involved are small. But budget-makers high in the departments or close to the President and in Congress are very much aware of their role when they compare the relative merits of competing proposals, especially when the programs are large and the stakes are high. In making their decisions, budget-makers are invariably influenced by a variety of factors. The official's own conception of the public welfare may lead him to favor one use over another; yet, his bias may be modified by what he knows the President or Congress or interest groups may insist upon. Thus, the final decision is the product of diverse values and pressures so complex

* A.B. 1947, Antioch College; Ph.D. I950, University of North Carolina. Assistant Professor of Political Science, Stanford University. Formerly member of the Program Staff (later Technical Review Staff), Office of the Secretary, United States Department of the Interior. Author, Public Administration of Florida's Natural Resources (i953), Science and State Government in California (I955). Contributor to political science periodicals. 
in their interrelations that no person may be entirely certain why a particular decision was made.

Because of the importance and complexity of the decision-making process, of which budgeting is an example, students of the behavioral sciences have devoted increasing attention to it in recent years. Students of government have, in particular, been concerned with increasing the rationality of the budget process, in the sense of maximizing the extent to which budget choices are made explicitly and deliberately. In this effort, public administration has sought to develop organizational arrangements and administrative procedures which facilitate the clear formulation and comparison of alternatives; and economics has sought to provide methods of analysis which reveal with increasing clarity the comparative utility of alternative expenditures.

Perhaps the most important contribution of the economists has been to focus attention on the fact that it is not profitable to discuss in the aggregate whether schools, for example, are "more important" than roads. The question that rather needs to be asked is whether the return will be greater from an incremental investment in schools or an equal investment in roads. If one million dollars is available, in which function should it be invested? The answer is found by looking at the marginal social benefit yielded by each of the functions. This is the concept which lies at the heart of marginal analysis as it is used by economists.

So stated, the problem of budgeting takes on a deceptive simplicity. Budgetmakers may attempt broad appraisals and independent judgments, but characteristically they find that not one, but numerous values need to be maximized and that these values more often than not conflict. Especially is this true of river basin development, where short and long-range goals and the competing demands of flood control, navigation, irrigation, and power development make conflict inevitable. But this is by no means the only problem. The comparison of utilities is made all the more difficult by the fact that value judgments cannot ordinarily be given quantitative expression and, in any event, cannot be compared with one another in terms of a common unit of value. Were it possible to reduce a variety of conflicting goals to a common unit of value, it would be possible, of course, to rank alternatives according to their comparative utility. But the depressing fact is that neither the Benthamite calculus nor any other system sufficiently lends itself to quantification to eliminate the need for intuition or other subjective mental processes.

Despite these qualifications, considerable progress has been made in recent years in the elaboration of forms of economic analysis which, when properly used, provide decision-makers with a quantified appraisal of the relative merits of alternative water development projects. While the misuse of economic analysis has been common in appraising these projects, it seems fair to say that the true goal of budgeting-the rational comparison of alternatives-is clearly capable of being achieved in the water development field.

Of the three agencies which construct river basin projects and employ economic analysis in their evaluation, the Army Corps of Engineers is the oldest. Although 
the Corps' origins go back to the Revolutionary War, it was not asked to undertake civil functions until 1824 , when Congress directed the Engineers to clear a navigable channel down the Ohio and Mississippi Rivers. This was the beginning of the Corps's function as "engineering consultants and contractors for the Congress." For nearly a century, the Corps was confined to navigation improvements, although flood control was often a by-product of its undertakings. Beginning in 1917 , however, Congress permitted the Corps to construct certain flood works on the Mississippi and Sacramento Rivers, and in the Flood Control Act of $1936,{ }^{1}$ it recognized flood damage as a matter of national concern and authorized the Corps to construct flood works of all kinds, including reservoirs, throughout the country. Since power was recognized as a by-product of reservoir construction, the Engineers were, in fact, thus permitted to enter the business of multiple-purpose river basin development. The Corps is well known, of course, for the pork-barrel legislation which authorizes its projects, for its close ties with local and national organizations which effectively support its program in Congress, and for its ability to circumvent presidential control. $^{2}$

The Bureau of Reclamation, established by the Reclamation Act of Ig02, $^{3}$ is the agency primarily responsible for the construction of public irrigation projects in the seventeen western states. Created as a logical extension of the homestead concept into the semiarid and arid West, the reclamation program has always been committed to the task of creating family-sized farms, which are visualized as supporting, in turn, numerous small but thriving urban communities. The social idealism of the reclamation program has been buttressed by the acreage and antispeculation provisions of various reclamation laws and by provisions of other laws which give preference in the sale of power to public and cooperatively-owned distribution systems. ${ }^{4}$ The social policies of the reclamation program have been both an advantage and a disadvantage to the Bureau in the struggle among competing agencies. The Bureau has won friends among liberal and idealistic groups, but the restrictive nature of the legislation under which it operates has made it comparatively difficult for large landowners to secure windfall gains or for project beneficiaries to escape an obligation to repay at least part of the capital costs of irrigation projects. All things considered, therefore, the Bureau has not had as good public relations as has the Corps, and its program has never been as generously supported in Congress.

The Flood Control Act of 1936 assigned to the Department of Agriculture responsibility for watershed management designed to prevent flood damage. The Department was not immediately geared to the implementation of such a program, apart from its ongoing responsibilities for soil conservation, and World War II super-

${ }_{49}$ STAT. 1570, 33 U.S.C. \$701a (1952).

2 See generally, Arthur Maass, Muddy Waters: The Army Engineers and the Nation's Rivers (195I).

32 STaT. 388,43 U.S.C. $\$ 39$ I (1952).

'See, e.g., 58 STAT. 890 (1944), I6 U.S.C. $\$ 825$ s (1952). For a description of acreage-limitation and antispeculation legislation, see U. S. Bureau of Reclamation, Dep't of thie INTERIor, Landowner. ship SuRvey on Federal Reclanation Projects (1946). 
vened before the program could be initiated. Hence, it was not until 1946 that Congress actually appropriated the first funds for watershed control. In the decade which has followed, Agriculture's program has shown no sign of rivaling in size those of the Corps and the Bureau. The Department of Agriculture has had no well-organized constituency to support its flood-control work, and the nature of its task lacks the dramatic quality of harnessing whole rivers with giant multiple-purpose dams. Then, too, the Corps and the Bureau have done what they could to secure congressional restrictions of one sort or another on the watershed program. Although Agriculture's program has remained comparatively small, its plans are big, and if support can be developed, its program may rival in size those of its two competitors.

\section{II}

\section{Economic Evaluation}

Because of the limitations of funds and the fact that projects in all parts of the country have their enthusiastic supporters, it has been necessary for Congress and the construction agencies to develop criteria for evaluating water development projects. Two general tests-financial feasibility and benefit-cost analysis-have been devised. When conservatively used, both provide decision-makers with quantitative information which makes it possible to rank projects in the order of their contribution to the general welfare, at least to the extent that this can be measured by tangible utilities and disutilities. The rank order is a rough one and must be qualified by our inability to quantify certain intangible factors (extramarket values) which may make projects more or less desirable; but these tests, when properly used, are capable of providing at least a rough guide to decision-makers.

The test of financial feasibility has been applied over the years only to irrigation projects. The Reclamation Act of 1902 provided that water users on federal irrigation projẹcts must contract to repay the capital costs of these projects, without interest, over a period of ten years. The interest subsidy was widely regarded as justified because of the national interest in the social objectives of the program; and in any event, it was a smaller subsidy than that provided for navigation and later for flood-control projects, which do not require repayment of capital costs. When the first settlers proved unable to meet the repayment requirements, Congress extended the period to twenty years in the Reclamation Extension Act of $1914,{ }^{5}$ then to forty years in the Omnibus Adjustment Act of $1926,{ }^{6}$ and finally to fifty years in the Reclamation Project Act of $1939 .^{7}$ Thus, although the period has gradually lengthened, the test has remained one of the ability of the settlers to reimburse the federal government for its investment in the project. Repayment ability, in turn, has been regarded as a measure of the worthwhileness of the project, since it reflects project costs, the availability of water, the fertility of the soil, and other factors which have a bearing on the comparative utility of projects.

${ }^{3} 38$ STat. 686.

${ }^{\circ} 44$ STAT. 636,43 U.S.C. $\$ 423$ C (1952).

${ }^{7} 53$ STAT. II87, 43 U.S.C. $\$ 485$ (1952). This act continued the forty-year repayment period but provided for an initial ten-year development period during which no payment is required. 
While any project meeting the test of financial feasibility might be authorized, the expectation was-and no doubt the practice has been-that the Bureau would seek authorization to construct those projects first which would "pay out" in the least number of years. In this sense, then, the test of financial feasibility provides a rank order of projects. In practice, of course, political and other factors have played an important role in determining the order in which projects are constructed, but this fact does not vitiate the statement that calculations of financial feasibility can provide decision-makers with valuable information which has the effect of sharpening alternatives and providing a more rational basis for reaching conclusions.

Benefit-cost analysis is perhaps a better test of the worthwhileness of a project, since it can be used to measure a wider range of factors than does financial feasibility. The use of benefit-cost analysis grew out of section I of the Flood Control Act of I936, which provided that: ${ }^{8}$

.. the Federal Government should improve or participate in the improvement of navigable waters or their tributaries, including watersheds thereof, for flood-control purposes if the benefits to whomsoever they may accrue are in excess of the estimated costs, and if the lives and social security of people are otherwise adversely affected.

Although the act applied specifically only to the Corps of Engineers and the Department of Agriculture, the Bureau of Reclamation found it expedient to join with the other agencies in efforts to elaborate a system of project evaluation which would meet the act's requirements. Benefit-cost analysis was the result. ${ }^{9}$ In this form of economic evaluation, two categories of benefits and costs are recognized: (I) tangible benefits and costs, which are susceptible of measurement in monetary terms; and (2) intangible benefits and costs (extramarket values), which cannot be converted to monetary equivalents. Almost necessarily, this form of evaluation places greater emphasis upon tangible benefits and costs, although the intangibles are not necessarily ignored. Customarily, tangible benefits and costs are reduced to dollar equivalents and expressed as a ratio of benefits to costs. If this ratio is in excess of unity, it is generally considered that the project is economically justified. Intangibles are compared qualitatively in prose form and, on the whole, play a rather unimportant role, at least in a formal sense, in project justification.

In the calculation of benefit-cost ratios, economists recognize two types of tangible benefits and costs-primary (direct) and secondary (indirect). Primary benefits

\footnotetext{
${ }^{8} 49$ STAT. 1570, 33 U.S.C. §701a (1952).

- A considerable literature has developed on this subject in the last few years. See Subcommitree oN Benefits and Costs of the Federal Inter-Agency River Basin Commuttee, Proposed Practices for Economic Analysis of River Basin Projects (1950); National Water Policy Panel of the Engineers Joint Councir, Principles of a Sound Water Policy (195r); House Committee on Public Works, Economic Evaluation of Federal Water Resource Development Rrojects, 82d Cong., 2d Sess. (1952); Clarenbach, Reliability of Estimates of Agricultural Damages from Floods, and Curran, Evaluation of Federal Navigation Projects, in 3 U. S. Conm'n on Organization of the Executive Branch of the Government, Water Resources and Power 1275, 1317 (1955) (second Hoover Commission Report); Wantrup, Benefit-Cost Analysis and Public Resource Development, 37 J. FARM. EcoN. 676 (1955); and Otto Eckstein, Benefits and Costs: Studies in the Economics of Public Works Evaluation (unpublished doctoral dissertation in Harvard University Library 1955).
} 
and costs are those that arise directly and immediately from the projects. Primary benefits include reduction of flood damage, increases in net income resulting from the higher use of property made possible by flood control, increases in net income from lands benefited by watershed treatment measures or rendered more productive by irrigation, savings in transportation costs resulting from navigation projects, and the value of power from a hydroelectric project. Primary costs include the actual cost of constructing the project, its operation and maintenance, losses in state and local tax revenues, and the abandonment of economically useful structures, such as locks and bridges.

Secondary benefits have been defined as "the values added over and above the value of the immediate products or services of the project as a result of activities stemming from or induced by the project."10 Those values "stemming from" a project are usually thought of as accruing from the processing of the products of a project, such as the milling, transportation, and baking of wheat produced on an irrigation project. Thus, the value of bread over and above the value of its wheat content would be a secondary benefit. Values "induced by" a project include the increase in economic activity resulting from expenditures by the producers of the immediate products of a project. These would include the increased income of local businesses that serve the project area. Secondary costs comprise the costs of further processing the immediate products or services of the project and the costs incurred by local businessmen in meeting the increased demand for goods and services in the project area. As a matter of convenience, it is customary to speak of net secondary benefits, which are equal to secondary benefits less secondary costs.

To the uninitiated, the calculation of a benefit-cost ratio may seem a fairly simple matter. But economists are not entirely agreed as to either the principles or the details of practice; and the agencies, driven by competitive and political pressures to find favorable ratios, have been unable to agree on what constitutes a benefit, how its monetary value should be determined, what amortization period should be used for structures, what interest rates should be considered applicable in financing, and whether or not net secondary benefits may legitimately be counted during periods of full employment. For more than a decade, the agencies, primarily through the Federal Inter-Agency River Basin Committee and its successors, have wrestled with these issues without reaching agreement. In 1952, Circular No. A-47, issued by the Bureau of the Budget, imposed a degree of uniformity of method on the agencies but left a number of questions unsettled, including the problem of secondary benefits.

Despite the complexities and unsettled problems of benefit-cost analysis, however, its ultimate objective should be kept in mind. This, in the words of the Subcommittee on Benefits and Costs, is to ${ }^{11}$

... ascertain the extent to which the use of economic resources such as the land, labor, and materials necessary for a project is more or less effective than would be the case if the project were not undertaken.

${ }^{10}$ Subcommtttee on Benefits and Costs, op. cit. supra note 9 , at 9.

${ }^{11}$ Id. at 5 . 
When properly used, it should result in a rank order of projects based on their relative efficiency in the use of economic resources. Benefit-cost analysis is, thus, a major aid to budgeting, in the sense that it facilitates the comparison of alternatives and creates an environment in which choices can be made explicitly and deliberately. Potentially, at least, it has much to contribute to a science of rational social choice.

\section{III}

\section{Reclamation Repayment and the Test of Financial Feasibility}

As we have seen, the early settlers on federal irrigation projects were unable to meet their repayment obligations in the periods of time specified in law. Accordingly, the repayment period was extended from ten years in 1902, to twenty years in r9r4, to forty years in 1926 , and finally to fifty years in I939. Despite these extensions in general law, it has frequently been necessary for Congress (I) to make nonreimbursable a portion of the construction costs of some projects, (2) to write off construction charges the settlers are unable to repay, and (3) to extend the repayment period beyond the fifty-year standard set in the Reclamation Project Act of r939. The sums involved in the first two categories are difficult to determine from bureau figures but are not large in terms of the total program. Settlers on a majority of the projects which have been in existence for some time, however, have, at one time or another, been unable to meet their repayment obligations, and Congress has found it necessary to extend the repayment period. Such action has the effect of increasing the subsidy to irrigation, since the federal government must continue to pay interest on the unpaid balance. Over a fifty-year period, at three per cent interest, the interest subsidy borne by the Government is approximately equal to the construction costs. When the repayment period is extended beyond fifty years, the subsidy becomes proportionately greater.

Because of the way in which reclamation repayment figures are published, it is difficult to determine precisely the repayment histories of many projects. ${ }^{12}$ However, Joss has made a study of the repayment record of twenty-seven projects which had received water by rgr $8 .^{13}$ His study carried these projects through 1938 . Of the projects he analyzed, five have been abandoned as having no hope of paying out and as likely to represent a continuing loss to the Government. Of the remaining projects, four will require more than $25^{\circ}$ years to pay out, five will require between 125 and $25^{\circ}$ years, six will require seventy-five to 125 years, and the remaining seven projects will pay out in less than seventy-five years, based on their repayment experience between rgr8 and 1938 .

More recently, a study by the Subcommittee on Irrigation and Reclamation of the House Committee on Interior and Insular Affairs revealed that in the five years between 1947 and 1952 , repayment contracts of eighteen projects were amended to

${ }^{13}$ See U. S. Bureau of Reclamation, Dep't of the Interior, Repayment Histories and Payout SCHEDULES-I952 (I953).

${ }^{13}$ Joss, Repayment Experience on Federal Reclamation Projects, 27 J. FARM Ecos. 153 (1945). 
extend the total length of the repayment period. 14 Six of these projects will now require periods in excess of roo years to pay out. Two additional projects will not return capital costs to the Government within their useful lives. One of these would require 328 years to pay out, if the project works were to last that long. The remaining ten projects are expected to pay out in from fifty to ninety-nine years.

Since the Bureau had constructed only seventy-one projects by 1952 , and since a number of these were, at that time, of such recent origin that repayment obligations had not fallen due, the conclusion seems inescapable that the test of financial feasibility is not serving its purpose. In actual fact, most of the projects with repayment histories of ten years or longer have needed some form of deferment or relief from repayment obligations. ${ }^{15}$

Despite the failure of reclamation projects to pay out as expected, the program has numerous supporters in and out of Congress, many of whom use economic arguments of dubious validity in defense of the program. Thus, the point is often made that nearly all projects are current in their repayment obligations. But such statements conveniently ignore the fact that delinquencies are periodically funded and, through an amendatory contract, result in an extension of the repayment period. The depressing fact rather is that in terms of their original contracts, most of the projects with a substantial repayment history are not current in their repayment obligations.

The defenders of the program also lay much stress on the argument that capital costs are repaid to the Government. While this is more or less true in fact, the great care with which these same advocates avoid any mention of the size of the interest subsidy-now more than fifty per cent of project costs-leads one to believe that they are less than candid with their audiences. However, it should be kept in mind that repayment on the part of irrigation beneficiaries is considerably greater than that of the beneficiaries of navigation and flood-control projects, the capital costs of which are borne almost wholly by the federal government. But despite this reservation, it seems clear that the test of financial feasibility serves more as window-dressing for the program than as a real test which proposed projects are expected to meet. No

\footnotetext{
1 Subcommittee on Irrigation and Reclamation of the House Committee on Interior and Insular Affairs, Construction Costs and Repayment on Federal Reclamation Projects, 82d Cong., 2d Sess. (1952).

${ }^{15}$ Many of the projects completed in recent years or still under construction have brighter repayment prospects. This is because the capital costs of these irrigation projects, through devices such as the "interest component" and the "basin account"-will be repaid from the "surplus" revenues of hydroelcetric projects. The Upper Colorado River Storage Project is a good example of a project made financially feasible only because power consumers will repay a substantial portion of the irrigation costs. Roy Huffman, in his Irrigation Development and Public Water Policy (1953), at p. 174, says: "Obviously, the basin account would discriminate in favor of irrigation development in river basins with great hydroelectric power resources. Specifically, it would make possible in one river basin (such as the Columbia) the development of irrigated lands which were inferior to lands in another river basin where the lesser power resources did not provide sufficient subsidy. Rather than aiding the expansion of public irrigation development throughout the West, the basin account system might tend to limit it to regions possessing great quantities of hydroelectric power." It can be argued, on the other hand, however, that the power subsidy to irrigation is a means of securing repayment aid from the secondary beneficiaries of irrigation projects. Nevertheless, we might be better off to pass up the hopelessly incficient irrigation projects and concentrate on straightforward power projects, with or without flood storage.
} 
doubt, it also serves a useful function as a means of comparing alternative projects, since the inflation of expectations has no harmful effect provided the degree of optimism does not vary among projects. But as a measure of whether a project should be constructed or the money be allowed to remain in private hands, the test does little more than throw a cloak of respectability around the program. If the projects are justified by a comparison of benefits and costs, then the test of financial feasibility might well be abandoned. Or if the public interest in irrigation justified public assumption of the interest charges for more than fifty years (resulting in a subsidy in excess of fifty per cent of the total cost of the project), Congress might appropriately change the standard to provide for a longer repayment period. But Congress has never been willing to do this, and one is led to conclude that the program receives its backing more from the political strength of its supporters than from any widespread feeling that its contribution to the public interest justifies a repayment period in excess of fifty years.

\section{IV}

\section{Benefit-Cost Analysis: Its Use and Abuse}

The second form of economic evaluation, benefit-cost analysis, is used by all three construction agencies. In this respect, it is unlike the test of financial feasibility, which is used only by the Bureau of Reclamation. As indicated above, economists are by no means in complete agreement on the details of benefit-cost methodology. But operationally useful definitions and approximations make it an effective tool of economic evaluation when properly employed. Unfortunately, its actual use by construction agencies raises grave doubts as to the reliability of the ratios that are calculated for the use of decision-makers. In this regard, two matters must be considered. The first concerns the legitimacy of counting secondary benefits, and the second has to do with the overestimation of primary benefits.

It will be recalled that secondary benefits are defined as the values added over and above the value of the immediate products or services of the project as a result of activities stemming from or induced by the project. These secondary benefits arise from the increase in economic activity accruing from the processing of the products of a project and the expenditures of the primary beneficiaries of the project. Secondary benefits, however, should be net of the costs incurred in secondary activities and should also be net of any surpluses in secondary activities that would be expected from other uses of project resources. In economic evaluation, the agencies have agreed to assume an expanding economy and the prevalence of relatively high levels of resource employment (i.e., full employment). These assumptions have generally been consistent with the facts during the years in which benefit-cost analysis has been employed. Under these conditions, it must be assumed that alternative opportunities exist for the use of project resources and that these uses would produce secondary benefits. From a national standpoint, it can be argued that the secondary benefits of one project are approximately equal in value to the secondary benefits 
that would arise if project resources were used in an alternative investment elsewhere, whether public or private. Therefore, on the assumption that the resources would be used elsewhere, there would be no net secondary benefits attributable to a project. Or, to word it somewhat differently, from a national standpoint, secondary benefits are approximately offset by secondary costs, if the latter include foregone opportunities to reap secondary benefits from public or private investments in other localities.

Two additional points, however, remain to be made. The first is that economists are generally agreed that water development projects have important net secondary benefits during periods of unemployment. Under depression conditions, alternative private investments would not necessarily be made, and, hence, there is no basis for insisting that the secondary benefits of a public project be reduced by the amount of secondary benefits that would accrue from a marginal alternative investment elsewhere.

The second point which needs to be made is that the analysis of secondary benefits presented above reflects a national point of view. Net secondary benefits, even in periods of full employment, do exist for regions and localities. If, for some reason, policy-makers wish to alter the pattern of income among regions, among industrial or occupational groups, or among individuals, the counting of at least certain types of secondary benefits becomes legitimate. Projects of this sort may not increase the real national income, but they can achieve a variety of social objectives. Needless to say, explicit statements of social objectives of this sort are seldom forthcoming from policy-makers, and in their absence, except under circumstances of unemployment, the counting of secondary benefits does not seem justified.

Of the three agencies under consideration here, only the Bureau of Reclamation counts secondary benefits in such a way that they play an important role in securing favorable benefit-cost ratios. The other agencies either do not compute them or ordinarily do so in such a limited way that their methods are not subject to criticism. The differences between the agencies on this matter lie at the heart of most of their disagreements on benefit-cost analysis. Although the Bureau has consistently stood alone in the secondary benefits debates of the Federal Inter-Agency River Basin Committee, its position is clearly dictated by the fact that most irrigation projects depend upon the counting of "secondaries" for favorable ratios. Indeed, in the justification of many projects, the Bureau depends more heavily upon secondary than upon primary benefits.

The agencies' disagreements are reflected in the report of the Subcommittee on Benefits and Costs and, at one time, were referred to a Panel of Consultants by the Bureau of Reclamation. ${ }^{16}$ In 1952, the dispute over secondary benefits was reviewed by a congressional committee (commonly known as the Jones Subcommittee), which made the following comments: ${ }^{17}$

\footnotetext{
${ }^{16}$ Panel of Consultants on Secondary or Indirect Benefits of Water-Use Projects, Repont to Michael W. Straus, Commissioner, Bureau of Reclamation (1952).

${ }^{17}$ House Committee on Public Works, supra note 9, at 51.
} 
Some of the effort to place monetary values on indirect [secondary] benefits is nothing short of ludicrous. It is time to stop using money and manpower on these refinements that serve only an expedient, self-deception....

It is the view of the subcommittee that even though those devising these computations may not realize their vulnerability, the higher authorities of the agencies who knowingly approve the use of such dubious factors seem to be deliberately participating in an attempt to mislead themselves if not the Congress and the public at large. The use of such hypothecated benefits in a computation would tend to create doubt in the validity of the entire presentation of the agency.

More recently, Professor Wantrup, who has devoted as much time as anyone to studying the economic evaluation of water development projects, supported the Subcommittee when he wrote: "When one tries to draw conclusions from this analysis of secondary benefits and costs, one is forced to suggest that all classes of secondary net benefits be dropped from consideration. . .."18

Although the counting of secondary benefits is frowned upon by most of the agencies and most economists, this fact has not restrained the Bureau's supporters from using a popular variation of the secondary benefits thesis, perhaps best described as the "pebble-in-the-pond" argument. According to this argument, irrigation projects are justified because of their far-reaching economic effects, which, like the ripples caused by throwing a pebble in a pond, spread out in concentric circles far beyond the immediate project area. This thesis was well stated by Senator Watkins in I955, when he argued that the Upper Colorado River Storage Project was justified because "it will provide a great increase in homes, jobs, national income tax, and individual contentment, as well as provide a second line of civil and military defense for the nation as a whole."19 What the Bureau's friends forget is that another pebble thrown into another pond would quite probably create just as many "secondary" and "intangible" ripples.

Although the Corps of Engineers and the Department of Agriculture have taken a pious position with regard to secondary benefits, recent evidence seems to suggest that these agencies have devised less conspicuous means of accomplishing the same end. This evidence leads to a consideration of our second major problem-namely, the apparent overestimation of primary benefits. The opportunities for this kind of maneuver become apparent when one reflects upon the kinds of estimates and projections which necessarily are incorporated into benefit-cost ratios. Such factors as crop yields, cost of production, and prices of agricultural products which would be produced on lands in proposed irrigation, flood-control, and watershed projects are, of course, not present facts, and estimates of these quantities are notoriously subject to wide margins of error. Much the same can be said of estimates of the kinds and quantities of materials which would be transported by water as a result of the construction of a navigation project. On the physical side, also, hydrologic science has not provided firm answers for many fundamentally important questions concerning

${ }^{28}$ Wantrup, supra note 9 , at 688.

${ }^{10}$ N. Y. Times, March 29, 1955, p. I7, col. 2. 
the behayior of water on and in the soil and in underground and surface reservoirs and streams. More or less informed guesses must be resorted to, for both physical and economic "data." This means that the door is open for various kinds of fudging, sometimes buried deep in bulky volumes of survey reports or in agency files.

In light of these obvious temptations, it is surprising that no central staff agency of the federal government has ever investigated the soundness of the actual field estimates of the benefits which find their way into benefit-cost ratios. The National Resources Planning Board might have undertaken this function, but it was abolished by Congress in 1943. It is a logical responsibility of the Bureau of the Budget, but insufficient staff or perhaps the political repercussions of such a move may have made it seem unwise. Why Congress has never seen fit to investigate the accuracy of benefit-cost calculations is perhaps more apparent. In any event, it remained for the second Hoover Commission's Task Force on Water Resources and Power to undertake such an inquiry.

An element of major significance in the evaluation of flood-control projects is the estimation of agricultural damages from floods. Many projects are "justified" by the Corps of Engineers and the Soil Conservation Service (Department of Agriculture) largely on the basis of claimed reductions of flood damage to agriculture and an associated land enhancement which results from the higher economic use to which land is put when protected from floods. Hence, the Task Force inquiry, conducted by Professor Fred A. Clarenbach, was directed principally to securing an answer to the question: "Are the estimates of agricultural flood damage and of land enhancement from flood reduction [made by the two agencies] reasonable and dependable?"20 The methodology of the inquiry involved an examination of the work-sheets of the two agencies and interviews with agricultural economists, independent appraisers, bankers, farmers, and others who are intimately acquainted with the productivity and value of agricultural land in a small number of basins in Kansas, Oklahoma, and Texas on which the agencies had recently completed calculations of benefit-cost ratios.

One area investigated comprised that reach of the Verdigris River, from the Toronto Dam site downstream to the upper limit of the Neodesha Reservoir, in southeastern Kansas. The area of cultivated land in the reach was reported by the Corps as $10,43^{\circ}$ acres, valued at an average of $\$ 94$ per acre. The Corps claims many benefits arising from construction of the Toronto Dam, but perhaps the most easily verified were direct crop damages and other direct damages to agriculture (including supplies, stock and equipment, land, and improvements) which the Corps claims will be averted if floods are checked by construction of the dam. Corps data, based on 1949 prices, indicate that in "flood free years" the "net earning power" per acre of cultivated land is $\$ 8.28$. For the same area, the Corps estimated average annual crop damages due to floods of $\$ 6.87$ per cultivated acre. Other estimated annual (noncrop) losses to agriculture came to $\$ 0.97$ per cultivated acre,

\footnotetext{
${ }^{20}$ Clarenbach, stupra note 9, at 1278 . The analysis which follows is taken entirely from this report.
} 
making a total average annual loss of $\$ 7.84$ per acre. If these corps figures are accurate, these flood losses leave a residual net return to cultivated land of only $\$ 0.44$ per acre. At a capitalization rate of five per cent, this annual return of $\$ 0.44$ would justify a land value of only $\$ 9$ per acre. Nevertheless, actual land values, as noted, are approximately $\$ 94$ per acre.

The most reasonable explanation for the evident inconsistency in the Corps's appraisal results would seem to be that direct flood damages were significantly overestimated. Clarenbach's interviews with farmers, professional hydrologists, and agricultural economists seemed to indicate that "the Corps does not take adequate account of what some informants considered were important net beneficial effects of some floods in improving moisture and soil conditions."21 Some farmers stated candidly that they did not get a good crop unless their lowlands were inundated during the spring.

Clarenbach also investigated the work of the Soil Conservation Service above Lavon Reservoir on the East Fork of the Trinity River in northwest Texas. In this area, the SCS is engaged in a program of installing runoff and waterflow retardation structures and soil-erosion prevention measures. On the basis of . I4,343 acres subject to flooding, the SCS estimates an average annual direct damage to crops and pasture of $\$ 34.98$ per acre. Yet the net residual return to flood-free bottom land averages only about $\$ 18$ per acre per year, after the deduction of production costs, taxes, and incidental maintenance charges. What the SCS is saying is that the farmers in this area annually lose more from flood damages than their land can produce even in a flood-free year! This is simply not believable. As Clarenbach says: "Though farmers are not perfect economic calculators, neither are they economic imbeciles."22

The analyses summarized above deal only with estimates of direct flood damages to crops and pasture. Both the Corps and SCS claim additional large benefits for indirect damages and for land enhancement. Clarenbach found these estimated benefits subject to equal or greater inflation. Hence, it is clear why Clarenbach refers to the economic evaluations now conducted by the agencies as a "considerable accumulation of absurdities,"23 why the Jones Subcommittee holds that benefit-cost analysis serves "only an expedient self-deception,"24 and why Wantrup -more given to scholarly understatement-says that "benefit-cost analysis can be and has been distorted and abused."25

The misuse to which benefit-cost analysis has been put must now be regarded as a matter of common knowledge among decision-makers high in the departments, in the Executive Office of the President, and in Congress. ${ }^{26}$ Not only has

${ }^{31} I d$. at 1283. $\quad{ }^{29} I d$. at 1290. $\quad{ }^{23} I d$. at 1298.

${ }^{24}$ House Committee on Public Works, supra note 9, at 5I.

25 Wantrup, supra note 9 , at 676 .

${ }^{20}$ The examples cited in the foregoing paragraphs deal with the overestimation of flood-control benefits. For analyses of navigation projects, see Curran, supra note 9, and Missouri Basin SURvey Comm'N, Missouri: LAND aNd WATER (1953). While the Corps of Engineers claimed $\$$ I $1,795,000$ annually as benefits from erosion control along the Missouri, the Missouri Basin Survey Commission estimated these 
the corruption of economic evaluation been noted by scholars, but the bureaucratic struggles of the great construction agencies have led to a series of reciprocal indictments which have laid the record open for all who care to look. Yet, the political pressures are such that serious interest in the reform of economic evaluation is conspicuous for its absence.

As presently used, benefit-cost analysis constitutes a clear and present danger because of the great influence which favorable ratios carry. In a culture such as ours, influenced as it is by the semantics of a market economy, it becomes near heresy to oppose an investment which, we are assured, will yield a sizable return. The idea of investment and return, neatly packaged in the form of a ratio incorporating only factors having a market value, has such a powerful command over the imagination that one can only credit the agencies with a master stroke in their adoption of this technique for the justification and defense of their programs. Again, as with the test of financial feasibility, there is little correspondence between what men know and what they say. Although many congressmen and certainly most agency decision-makers are aware of the debasement of benefit-cost analysis, the survey reports are full of them, and in their speeches, congressmen assure their colleagues that the nation cannot afford to forego the opportunity to make investments which will yield an excess of returns.

Another problem created by the heavy dependence upon benefit-cost analysis is the subordination of intangible benefits and costs in economic evaluation. These, it will be recalled, are benefits and costs which are not readily reduced to monetary equivalents. Often they are referred to as extramarket values. By whatever name they are called, they are real and often of great significance; and nearly all economists agree that they should be considered in project evaluation. Included among the intangibles are scenic and recreational values (including wildlife), the saving of human life through flood control, strengthening the national security, and the encouragement of a more widely-dispersed industry. The importance of these values will be appraised quite differently by different individuals, but that does not lessen their significance nor warrant their being ignored in project evaluation. The usual suggestion is that these values be outlined and evaluated in prose form. Yet, experience shows that agencies are unwilling to recommend projects with unfavorable ratios, even when a strong case can be made for them on the basis of intangible benefits. Perhaps this dilemma need never arise, because of the ease with which favorable ratios can be manufactured. But it seems partly, at least, to be a product of our dependence upon the symbols of the business world, and to this extent, the emphasis which the agencies and Congress place upon benefit-cost ratios detracts from the consideration which important extramarket values might otherwise receive.

at $\$ 964,000$. Annual savings due to the navigation project the Corps estimated at $\$ 6,699,000$, while the Commission estimated them at $\$ 2,050,000$. For the navigation project as a whole, the Corps calculated a benefit-cost ratio of 1.9 to $\mathrm{r}$; the Commission arrived at a ratio of 0.8 to $\mathrm{r}$. 


\section{Extramarket Values: Cloak for Self-Interest?}

It is a characteristic of politics that self-interest often masquerades in the form of lofty principle, for only in this fashion can it achieve the widespread public support which it needs. Thus, Locke took pen in hand after the Glorious Revolution to provide a theoretical defense for what had taken place, and the American Revolution was ably justified by Paine, Jefferson, and others using arguments which perhaps had comparatively little to do with the real issues of the controversy. Much the same can be said of many arguments offered in justification of river basin projects.

Clearly, many supporters of water development projects come to their position because of the important intangible public benefits provided by such projects. The preservation of lives through flood control and the enhancement of scenic and recreational values are perhaps the most unchallengable of these. But other justifications are set forth which inevitably lead the observer to wonder how sincerely they are offered and to what extent they are used to cloak objectives of more immediate self-interest. This concern becomes all the more important when one realizes the huge stake which contractors, navigation interests, shippers, landowners, and others have in the enormous subsidies provided through water development projects. In this part, we shall examine some of the arguments which have been most powerful in mobilizing support behind these programs. Because of the writer's familiarity with the reclamation program, most of the illustrations are drawn from it. Equally good examples, however, could be drawn from floodcontrol, navigation, power, and watershed-control programs.

Perhaps the most powerful force operating in support of the reclamation program has been a consistent interest on the part of our people in development of the West. For many, this nation has had a "manifest destiny" first to push back the frontier and then populate and develop the West. This has been America's challenge, and one generation after another has had its imagination captured by the romance of subjecting western lands and water to human control. From Horace Greeley's "Go West, Young Man" to the recent Davy Crockett craze, America's fascination with the West has remained undiminished.

Much of the interest in irrigation in the West has been stimulated by outright promoters. One of the most influential of these was William E. Smythe, who wrote The Conquest of Arid America (1899), which included chapters entitled "Greatness by Continental Conquest," "The Better Half of the United States," "The Blessing of Aridity," and "The Miracle of Irrigation." From Smythe's day to present times, the West has had its advocates. Thus, Clarence Davis, while Under Secretary of the Department of the Interior, told an audience: ${ }^{27}$

\footnotetext{
${ }^{27}$ Speech before the Idaho State Reclamation Association, Idaho Falls, Idaho, April 25, I955. Interior Department News Release, April 25, 1955.
} 
It is a great program to which the Bureau of Reclamation was originally dedicatedthe development of the land and water resources of the West. We should revise our thinking. We should look at those things which are of fundamental importance. We should strive to build the West.

The logical conclusion to much of this kind of promotional argument is the doctrine that the West has a right to be developed, even though alternative investments elsewhere would add more to the real national income. This is the official position of the Department of the Interior. Writing in criticism of a Bureau of the Budget directive which provided that projects should be evaluated, in part, on the relative economy of alternative means available on a national basis for meeting the needs to be met by the project, Ralph Tudor, while Acting Secretary of the Interior, said: ${ }^{28}$

The Reclamation program is basically a Western States land and water resource development program.... In an Interior report there is no occasion for comparing the relative merits of a proposed Federal irrigation development with some other reclamation possibilities, such as draining of swamp lands. The basic test should be: ( $x$ ) whether a proposed development is needed and is favorable from an economic standpoint; and (2) its relationship to a balanced over-all national program. With respect to test (2), State and iegional needs .... may outweigh considerations resulting from strict economic evaluation on a national basis. This element of balanced development . . . may be disregarded if emphasis is placed on nation-wide competition of alternatives.

Thus, we have the view that "balanced development" requires that regions be developed more or less equally, or on some other "fair" basis, even though alternative investments in other regions-perhaps already more highly developed -might contribute more to the real national income. Promoters and those with vested interests to defend are not always alone in this point of view. The growth of regionalism as a concept and as an aid to analysis in economics, sociology, geography, and political science has perhaps caused some scholars to hold regional values higher than national ones. ${ }^{20}$ Thus, William E. Folz criticizes Wantrup for failing to "consider as a benefit the psychological value society derives from the development of a region."30 Points of view such as this raise serious philosophical and economic questions, which, needless to say, merit the most careful attention. Clearly, one cannot satisfy such "psychological values," if they really exist, and, at the same time, maximize the economic returns from either public or private investment. Inevitably, one is led to ask whether those who defend

\footnotetext{
${ }^{28}$ From a memorandum entitled "Comments and Recommendations for Revision of Bureau of the Budget Circular No. A-47," attached to a letter from Ralph A. Tudor, Acting Sccretary of the Interior, to Joseph M. Dodge, Director, Bureau of the Budget, Jan. 14, 1954.

${ }^{20}$ For a discussion of the role which regional analysis can play in each of the social sciences, sec Garnsey, The Dimensions of Regional Science, in 2 Papers and Proceedings of the Regional Science Association 27 (1956):

${ }^{30}$ In Water Resonrces and Economic Development of the West: Benefit-Cost Analysis, a paper presented at the meeting of the American Association for the Advancement of Science, Dec. 27, 1954, Berkeley, Cal.
} 
regional values are not really interested primarily in the development of their own region.

A second justification of the reclamation program is that it creates farm homes and their dependent, small urban communities. In the Bureau's publications, these values are referred to as settlement opportunities. There is little doubt that the Reclamation Act of rgo2 was regarded as a home and community-building measure. The I60-acre limitation of federal reclamation law, reiterated in legislation more than a dozen times in forty years, ${ }^{31}$ is clearly designed to promote the creation of family-size farms. This goal was and still is regarded by many as important enough to justify heavy subsidy to the irrigation program.

This justification of the reclamation program has its roots in a romantic attachment to an earlier day-to farming as a stable, sound way of life which is worth preserving in a world of uncertainties, radical ideologies, and unsettling social changes. Much of the writing in defense of the irrigation program is antiurban in outlook. Thus, an important Interior official recently said: $:^{32}$

There are millions of acres of underdeveloped land in the West ..., much of which can be the scene of comfortable farms, of thriving communities and a much happier life for many of our people than they can lead in the congested industrial centers and big cities of other parts of the country.

And an Interior publication, justifying the Missouri Basin Project, says of irrigated areas $:^{33}$

They will provide a land-use situation that will help stem the present tide of urbanization by throwing out into the area a series of life-lines, which will help hold a stabilization line below which the proportion of rural population in the area may be kept from falling.

Thus, much of the writing in defense of the irrigation program appeals to a lingering dissatisfaction which the urban majorities of the East have in their mode of living and capitalizes on a romantic attachment which nearly all Americans have to farming as a way of life.

A closely related objective of the reclamation program is the stabilization- of human occupancy of the Great Plains. Because of extreme variations in the amount and distribution of rainfall, farming and ranching on the plains have always been hazardous undertakings. The inevitable problems of wresting a living from the soil under the conditions prevailing on the plains was complicated historically by the fact that the men and women who peopled the West brought with them a background of experience in lands of greater humidity and tried to impose their ways of farming on this new land. The result has been an unstable agriculture and, at times, the emergence of problems of truly national concern-as illustrated by the dust bowl of the r930's and the current distress in the drought-stricken Southwest.

\footnotetext{
s1 See U. S. Bureau of Reclamation, op. cit. sipra note 4 , at 29.

${ }^{32}$ Clarence A. Davis, Under Secretary of the Department of the Interior, Release, supra note 27.

${ }^{23}$ Ickes, Missouri River Basin, S. Doc. No. 19r, 78th Cong., 2d Sess. 145 (1944) (emphasis supplied).
} 
An important defense of the irrigation program in the Missouri basin, where project beneficiaries are able to repay only a small fraction of capital costs, is based on this concept of "stabilization." Thus, one of the authorizing documents for the Missouri Basin Project states: ${ }^{34}$

There is not enough water in the Missouri River to irrigate the entire basin, but tiare is enough to create hundreds of islands of safety, some stretched like necklaces of narrow ribbons along streams in the basin; some larger blocks created by the diversion of available waters to irrigable areas.

These "islands of safety" are expected to provide a safe type of agriculture for the families living on them, supplementary feed and forage for adjacent dry-land farmers (thus reducing the need to liquidate valuable livestock during drought years), and a steady flow of high-value agricultural products, the processing of which will provide employment in the area, even during years of deficient rainfall.

The "stabilization" argument is sometimes extended to include the "rescue of stranded areas." This was the avowed objective of the Central Arizona Project, ${ }^{35}$ which was never authorized by Congress. This project was designed to bring water to 150,000 acres of land which had only insecurely been brought under cultivation in the first place. The project would have cost more than a billion dollars, none of which could have been repaid by the farmers. While this project never secured congressional approval, it differs only in degree from numerous others in the Missouri basin.

Many other arguments are, of course, also offered in justification of the reclamation program. Some, like the argument that projects result in an increase in federal income taxes, are only variations of the secondary-benefits argument and have no validity during periods of full employment, since alternative investments would produce the same effects. Others in this category include the arguments that projects provide "additional employment opportunities" and provide "new wealth where none existed before."

Our interest in these extramarket values stems from a concern about their validity. Social scientists are presented here with a difficult question: Do Americans "really" wish to develop the West, create settlement opportunities on new farms, or stabilize agriculture on the Great Plains, despite the fact that these ventures are often uneconomic in the sense that their benefit-cost ratios, if legitimately calculated, would be less than unity? Or are these justifications merely designed to cloak the desire for subsidy, windfall gains, or other forms of economic advantage which are an inevitable accompaniment of these projects?

We know that powerful economic interests have much to gain from water development projects. The irrigation and watershed programs are heavily subsidized, and navigation and flood control beneficiaries return no part of the capital

${ }^{34} I d$. at I 44 .

${ }^{35}$ See U. S. Bureau of Reclamation, Dep't of the Interior, A Report and Findings on Central Arizona Project, H. R. Doc. No. 136, 81st Cong., ist Sess. (1949). 
costs to the federal treasury. And we know that the economic interests which benefit from these projects are well-organized. According to Huffman, the National Reclamation Association "is made up primarily of the representatives of chambers of commerce, agricultural development departments of railroads, real estate agencies, and promotional groups in general," and membership in the National Rivers and Harbors Congress "is heavily weighted with representatives of the construction industry and allied businesses-people whose future depends on the type of work involved in river and harbor improvements." ${ }^{36}$ We know also that the roughly 50,000 employees of the three agencies under consideration here constitute a huge bureaucracy with an enormous stake in the continuation and expansion of their programs. ${ }^{37}$

Unfortunately, we are dealing here with complex problems of human motivation. The human mind is sufficiently pliable that basic motives are often masked, even from the person involved, by elaborate rationalizations. The real and the unreal, the true and the untrue are inextricably intertwined. The depressing fact is that the behavioral sciences have no ready means of probing motivations or of sorting hierarchies of values to determine which are held in their own right and which serve merely as cloaks for others. Thus, the extent to which projects enable us to realize important extramarket values, as opposed to masked self-interest, is, for the moment, unanswerable, at least in precise terms. In the following part, however, we will consider means by which more attention, of a rational and analytical sort, can be brought to bear on the problem of extramarket values.

\section{VI}

\section{Should Economic Evaluation Be Abandoned?}

If the analysis presented in the foregoing sections is valid, economic evaluation is failing in its purpose, which is to aid us in the rational comparison of alternatives. The repayment requirement of reclamation law has been administered in such a way that project beneficiaries are required to repay capital costs only to the extent of their "ability." Since the standard is not an absolute one, despite the requirements of the law, it loses much of its value as a measuring rod, although admittedly it may be of some use in weeding out the least efficient projects-especially if they have comparatively little political support. Much the same has happened to benefit-cost analysis. If our analysis is correct, this form of economic evaluation has been corrupted by zounting secondary benefits during periods of full employment and by the excessively optimistic estimation of direct benefits. All the agencies seem guilty, and one can only conclude that political pressures, interagency competition, and bureaucratic self-interest dictate that enough favorable ratios be "found" each year to keep the several programs going at a "desirable" level of activity.

The question must then be asked: Should economic evaluation be abandoned

${ }^{30}$ Hufrasan, op. cit. supra note 15 , at 180 .

${ }^{37}$ See de Roos and Maass, Tke Lobby that Can't Be Licked, Harper's Magazine, Aug. I949, p. 21. 
because it is misleading and does more harm than good? Wantrup has asked this question and answered it in the negative. He argues first that "economic and pseudoeconomic arguments are by far the most important weapons in the arsenal of opposed regional, industrial, and occupational interests contending in the political arena for or against a public project," and that benefit-cost analysis in the hands of the Government "serves a worth-while purpose to restrain the abuse of economic arguments in the political process." ${ }^{38}$ The facts, however, point in the opposite direction. Governmental calculations of benefits and costs cannot be used to restrain the abuse of economic arguments, because these calculations are themselves unreliable and misleading. In fact, it seems fair to say that government agencies contribute nearly as much to the abuse of economic arguments as do private interests. Perhaps the net effect of benefit-cost analysis by government agencies is to undermine public confidence in the arguments of those who attach little weight to extramarket benefits and hold that many projects should not be constructed because they are uneconomic. This defense of benefit-cost analysis, then, seems untenable.

Wantrup's second defense of benefit-cost analysis is that it is worthwhile "because of its stimulating effects in expanding scientific understanding of the physical as well as social problems in public resource development." ${ }^{38}$ In support of this position, he argues that the persistent quest of those who calculate benefit-cost ratios for additional quantitative information has stimulated research in the physical problems of flood control, reclamation, and land management. One can grant this argument, however, without agreeing that the benefits to the physical sciences are worth the price we pay through the misinforming of decision-makers. As for the social sciences, it is probably true that benefit-cost analysis has focused attention on the decision-making process and on the factors which play a role in it. The development of a small, but growing, literature on the subject is evidence of that. But its more general and important effect is to narcotize any real public interest in project evaluation. The symbols of the market economy are so powerful in America that the public is soothed into near unconsciousness when told by an authoritative government agency that the returns from a project will exceed its costs.

Must our question, then, be answered in the affirmative? I think not. Fortunately, the abuse of economic evaluation by government agences does not, by itself, lead to the construction of many projects. The political forces at work are such that most projects would probably be authorized in any event, although the process might be a bit more embarrassing in the absence of the appearance of respectability which economic evaluation provides. But the positive case for economic evaluation rests on the enormous contribution which it could make to the decision-making process and, through it, to rational social action. Properly conducted, economic evaluation can provide a valuable comparison of alternatives in terms of those direct benefits and costs which can reasonably be reduced to dollar values. And if, as seems likely,

\footnotetext{
${ }^{38}$ Wantrup, supra note 9, at 677 .

${ }^{39} \mathrm{Id}$. at 678 .
} 
many of these ratios were near or below unity, this fact would focus attention on much of the loose justification of projects in terms of their extramarket values. One could reasonably expect that alleged benefits such as "the psychological value society derives from the development of a region," creating settlement opportunities, and harnessing untamed rivers would be subjected to far more searching scrutiny by the public and by decision-makers in particular than is the case now, when padded ratios lull us into a false sense of security.

If the case for economic evaluation rests upon its enormous potential contribution to rational decision-making, how can it be made to fulfill its purpose? The answer is fortunately simple: effective control under a strong unit in the Executive Office of the President. Such a unit must be wholly independent of the construction agencies, and it must have the power (I) to establish standards and procedures for economic evaluation, and (2) to audit the working papers of agency economists and physical scientists in the field. Human nature and political pressures being what they are, the construction agencies cannot be trusted to produce objective economic evaluations. Action to provide an independent check on the construction agencies could quite probably be taken under presidential authority alone.

American political arrangements are such that most units in the Executive Office of the President are not wholly free of political pressure. The unit suggested above would unquestionably be even more free to pursue its assigned task if Congress were willing to enact legislation to require that direct beneficiaries of all water development projects return a substantial share of project costs to the federal treasury. The repayment requirements of reclamation law, to some extent, eliminate pressures for construction of the least economic projects. The extension of a similar requirement to navigation and flood-control law could hardly help but have a sobering influence on those who now press for utterly uneconomic programs of water resource development. 